\title{
From fishing and factories to cultural tourism: the role of social entrepreneurs in the construction of a new institutional field.
}

\author{
Dr Breda McCarthy*
}

School of Business, James Cook University, Townsville, QLD 4811, Australia

\begin{abstract}
Starting from the premise that cultural tourism is a new institutional field, this article explores the construction of cultural tourism in regional Ireland. The article proposes an institutional framework which consists of three main drivers of change: 'government policy', 'resourcemobilisation opportunities' and 'social entrepreneurship'. It is argued that the development of cultural tourism was made possible by the unique networks of relationships and associations that underpin music, festival and language fields. The study is situated in the literature on neoinstitutional theory, and it draws on a model of change (Seo and Creed, 2002) to explore how cultural tourism was shaped by powerful historical, political and cultural forces over time.
\end{abstract}

Keywords: social enterprise, cultural tourism, neo-institutionalism, strategic change

\section{Introduction: the emergence of new institutional fields}

The analysis of how new institutional fields emerge is quite rare in the literature (DiMaggio, 1991; Lawrence and Phillips, 2004). Institutional fields consist of "those organisations that, in the aggregate, constitute a recognised area of life" (Di Maggio and Powell, 1983: 148). The concept of an institutional field incorporates practices, understandings and rules, together with a network of organisations (Di Maggio, 1991; Tolbert and Zucker, 1983) and cuts across traditional industries (Lawrence and Phillips, 2004). Studies of new institutional fields include management accounting (Burns and Scapens, 2000), commercial whale-watching (Lawrence and Phillips, 2004), temporary work agencies (Koene, 2006) community social welfare (Mohr and Guerra-Pearson, 2009), commercial recycling industry in the US (Lounsbury et al. 2003) and tourism in North Cyprus (Alipour and Kilic, 2003). The development of a 
new field is often "ambiguous and contested", the subject of "ongoing transformations by motivated actors" (Laurence and Phillips, 2004: 694). Changes in practices often occur as a result of "innovations at the periphery of the field which migrated to the core after they have been shown to be effective" (Lounsbury and Ventresca, 2003: 468).

The institutional field chosen for study was cultural tourism in Ireland. Cultural tourism is attracting increasing interest in the social sciences (Gibson and Connell, 2003; Prentice, 1993; Pearce, 1987; Richards, 1994; Urry, 1990). According to Richards (2001:7), cultural tourism can be conceived as "a dichotomy between culture and tourism" and the distinction between cultural tourism and other forms of tourism lies in the learning function. Cultural tourists learn about the processes (i.e., ideas, way of life of people) and products of a culture (i.e., buildings, artefacts, the arts and atmosphere). Heritage tourism is part of the broader category of cultural tourism but is more 'traditional' with its emphasis on recycling the past via museums and monuments (Richards, 1996). Culture is valorised by policy makers as a means to secure a unique advantage in a competitive marketplace, and it enables artists and cultural producers to earn income from the tourist market (Getz, 1991; Zeppel and Hall, 1991).

Tourist destinations are increasingly being recognised as socio-cultural constructions rather than simply physical locations. Scholars argue that "historical, political and cultural discourses influence how people and places are seen and represented in contemporary marketing" (Pritchard and Morgan, 2001: 167). In other words, a place has no objective reality. Its social connotation is not given but negotiated; different people may conceive it in different ways (Cohen, 1988). The branding strategies adopted by Irish tourist and development boards promote a distinctly Irish identity. There has been a move from 'heritage tourism' to 'living culture' (Fáilte Ireland, 2007a) with the promotion of diverse, memorable experiences such as the friendliness of the people, Irish music, song and dance, festivals and the contemporary arts. Branding activity is evident in tourism websites, road signage and advertising campaigns. Festival and event guides are produced and associations such as AOIFE (Association of Irish Festivals and Events) have emerged and codes of best 
practise are being developed. A new agency has been established, 'Culture Ireland', in an attempt to link the Arts with Tourism.

Cultural tourism, it is argued here, meets the basic characteristics of an institutional field: cultural tourism is a recognised area of life characterised by distinct institutions and inter-organizational networks (Lawrence and Phillips, 2004). An interesting research problem, therefore, is how social entrepreneurs bring about changes in values and norms in the institutions in which they themselves are embedded? This article draws on a model of institutional change (Seo and Creed, 2002) to explore how the Irish brand was shaped by powerful historical, political and cultural discourses. Irish policy makers pursued a strategy of economic development in the Gaeltacht (Irish-speaking areas in Ireland) from the 1960s to the 1980s which centred on employment growth via the development of factories, hotels, holiday homes and the attraction of inward investment. The strategy was well-intentioned, but certain aspects sidelined cultural tourism and threatened the survival of the language. Today, however, conceptualisations of tourism are firmly centred on living culture. The Irish language, once marginalised, has been enrolled in tourism strategy. A key force driving institutional change is social entrepreneurship, the impact of which is felt in the flourishing of cultural associations, Irish language schools and community festivals.

This article contributes to the literature on three levels: theoretical, methodological and empirical. Firstly, a theoretical framework is developed that connects the emergence of a new institutional field with resource mobilisation opportunities, government policy and social entrepreneurship. Secondly, a longitudinal approach is taken. Thirdly, examples are given of cultural tourism initiatives drawn from parts of County Kerry, Ireland. While the case study serves as a model for other destinations, it also illustrates some of the challenges faced by stakeholders. 


\section{Literature review: institutional theory}

The institutionalism paradigm has been used in a number of disciplines, including economics, organisation studies and political science. Institutional theory, according to Barley and Tolbert (1987: 93), highlights cultural influences on decision-making, and holds that organisations, and the individuals who populate them, are "suspended in a web of values, norms, rules, beliefs and taken-for-granted assumptions, that are at least partially of their own making." North (1990: 3) defines institutions as the "rules of the game" in society which he recognises as formal (constitutions, property rights, contracts, etc) or informal (norms and customs). North (1990: 5) makes a clear distinction between institutions and organisations, arguing that how organisations come into existence and how they evolve are fundamentally influenced by the institutional framework. North's (1990) work is relevant to business researchers since it is attuned to ideology and rejects the primacy which is accorded to the market. Another definition of institutions comes from Burns and Scapens (2000: 4) who define an institution as "a way of thought or action of some prevalence and permanence, which is embedded in the habits of a group or the customs of a people".

There are two perspectives of institutions and this study adopts the 'new institutionalism' perspective. Old institutional theory tends to emphasise inertia, persistence, passivity and determinism of the institutional context (Fernández-Alles and Valle-Cabrera, 2006; Greenwood and Hinings, 1996). It offers a good deal of insight into the factors that give rise to institutional stability. Theorists seek to explain the persistence of inefficiency and non-economic rationalities (North, 1990) and the bias towards the status quo (Burns and Nielsen, 2006). Institutional pressures force organisations to adopt similar practices or structures to gain legitimacy and support. Institutional isomorphism (a constraining process that forces one unity in a population to resemble other units) explains the prevalence of imitation and similarity (Di Maggio and Powell, 1983). In some cases, institutions are so powerful that organisations and individuals are apt to automatically conform to them. Scholars highlight the notion of path dependency: the potential for lock-in, in which initial choices preclude future options, including those which would have been more effective in the long run (Powell, 1991). 
'New institutionalism', in contrast, has its origins in the seminal work by Meyer and Rowan (1977). They associate conformity with the demands of regulatory agencies and utilisation of rewards and sanctions. The literature recognises a paradox: how can actors change institutions when they are conditioned by the very institutions they seek to change (DiMaggio and Powell, 1991). Yet, major change can take place. Barley and Tolbert (1987) offer the acquisition of suffrage by women in the United States and the dismantling of apartheid in South Africa as examples of institutional change. Scholars (Mair and Martí, 2006; Kalantaridis, 2007) propose that social entrepreneurs act as a catalyst for social change by subverting longestablished institutions. Researchers (DiMaggio, 1988; Dorado, 2005) use the notion of institutional entrepreneurship to explain how institutions change. They temper notions of determinism with ideas of discretion and strategic compliance, rooted in power and self-interest. Likewise, the sociologist Giddens (1984) adopts a balanced position and treats influences of structure and agency equally. One study found the seeds for change in human agency, isomorphism (or mimicry) and the institutional context (Koene, 2006). Human agency refers individuals' ability to intentionally pursue self-interest and to have some effect on the social world, altering the rules or the distribution of resources (Scott, 2001). Scholars also recognise that institutions vary in their normative power. Institutions that have a relatively short history or that have not yet gained widespread acceptance are more vulnerable to challenge and less apt to influence action (Barley and Tolbert, 1987). The state also plays a role in reforming institutions, and is "designer, defender and reformer of many formal and informal institutions" (Ha-Joon, 1994: 298).

Seo and Creed (2002) provide a useful understanding of institutional change which is illustrated in Figure 1. Further references to this model will be made throughout this article.

\section{INSERT FIGURE 1 HERE}

Seo and Creed's (2002) model breaks down the process of institutional change into four elements: (1) Social interactions (2) Institutionalization (3) Multi-level, mutually incompatible institutional processes (4) Conflicts and tension. Institutions are continually produced and reproduced by social interactions (social construction). However these institutions produce a complex array of interrelated, but mutually 
incompatible, institutions (totality). This leads to tensions and conflicts within and across institutions (contradiction). The ongoing experience of contradiction eventually leads to the transformation of social arrangements (praxis). Praxis refers to human agency of a political nature, which, though embedded in existing institutions, attempts to influence and secure change. Praxis helps break down organisational inertia. Institutional change is seen as an historical, dynamic and complex process and the outcome of political struggle among participants with unequal power.

\section{Social entrepreneurship and the role of local actors in shaping institutional change}

A social entrepreneurship perspective is particularly important in this study because social entrepreneurs can shape people's beliefs, attitudes and behaviours and influence the development of a new institutional field. With regard to the influence of entrepreneurs on policy change: "there has been precious little conceptual and empirical research in this area" (Kalantaridis, 2007: 440). According to Mair and Martí (2006: 40) there is "potential for the social entrepreneurship phenomenon to inform theory on institutional entrepreneurship", particularly since Di Maggio's (1988) theory of institutional entrepreneurship is explicit about the paradox of embedded agency. Social entrepreneurs are less embedded actors since they are likely to challenge rules, norms and dogma when they form social enterprises. This article is interested in exploring if, and how, social entrepreneurs subvert institutions? The literature to date remains inconclusive on the role played by social entrepreneurs in the emergence of a new institutional field.

What is social enterprise? The Organization for Economic Cooperation and Development (1999:10) defines social enterprise as "any private activity conducted in the public interest, organized with an entrepreneurial strategy, but whose main purpose is not the maximization of profit, but the attainment of certain economic and social goals." Social enterprise is based on principles of voluntarism, ethical behaviour and a mission with a social cause, such as combating poverty or tackling social exclusion (Chell, 2007). Social entrepreneurship is exercised when some person aims to create social value, recognizes and pursues opportunities to create this value, employs innovation, tolerates risk and declines to accept limitations in available resources (Peredo and McLean, 2006). Social enterprises are significant 
users and reproducers of social capital (Evers and Schulze-Böing, 1997). Social capital is defined by Putnam et al., (1993: 167) as "features of social organisation, such as trust, norms and networks that can improve the efficiency of society by facilitating co-ordinated action". Writers propose that social entrepreneurs can have a strong impact on regional development, even in divided societies such as Israel (due to the protracted Israeli-Palestinian conflict), provided they engage in conflict engagement (Friedman and Desivilya, 2010).

The relationship between social entrepreneurship and institutional change has rarely been studied. For this reason, this article poses the following research question: What impact do social entrepreneurs have on the emergence of a new institutional field, namely the construction of cultural tourism? The research methodology employed to examine this research question is outlined in the next section. 


\section{Research Methodology}

Field analysis necessitates attention to cultural beliefs, government regulation, economic conditions and consumer demand (Lounsbury and Ventresca, 2003). Barley and Tolbert (1987) propose that institutional researchers need to capture contemporaneous accounts, together with historical and archival data, in order to avoid biased interpretations of data (Barley and Tolbert, 1987). The current study of cultural tourism was sensitive to the role of contextual factors in the development of a new field, such as the growth in world tourism, the Irish economy (and its rapid growth - during the 1990s and early 2000s - and more recent dramatic decline), the role of the Irish Diaspora in shaping demand for Gaelic cultural products, debates about minority languages and the nature of tourism in academic circles, and learning from the experiences of other tourist destinations.

In order to understand the conditions that preceded the development of the cultural tourism field and to examine how conceptualisations of cultural tourism changed over time, general questions were posed during the research process (such as how planning occurred, who was involved, what worked well, how things changed over time). In this sense, the study takes a historical approach, exploring the past twenty years or so. Over time, a shift towards language-based tourism was identified. To understand this phenomenon, interviews with officials responsible for the development of the Gaeltacht was utilised as core data. As the study progressed, the research questions evolved from a concern with understanding cultural tourism in general, to understanding living culture which manifests itself in music, festivals and language. Theory development, data collection and analysis took place concurrently, so this study is grounded in the methodology of Glaser and Strauss (1967).

A case study region was selected, which was the Gaeltacht and peripheral Gaeltacht areas in county Kerry, the south-west of Ireland. Maps are included in Figures 2 and 3.

INSERT FIGURE 2 and 3 HERE 
Data shows that tourism revenue in the South West has increased by $10.6 \%$ since 2001. Outside of the capital city, Kerry (along with Cork) has the largest inventory of tourist infrastructure in the country and $15 \%$ of its workforce is employed in the tourism industry (Kerry County Council, 2009). Some facts and figures on the tourism resource of the Gaeltacht area (County Kerry) are offered in Table 1.

\section{INSERT TABLE 1 HERE}

The core primary data collection phase involving interviews, took place between June and December 2007. A judgement sample of 36 key informants was selected. They were chosen based on their positions, experiences, and availability. They included festival committees, owners of cultural tourism-related enterprises, managers of Art Centres and interpretative centres, local artists, and policy makers within Fáilte Ireland, the Arts Council and Údarás na Gaeltachta. Table 2 offers a profile of the respondents.

\section{INSERT TABLE 2 HERE}

This approach may have created an accessibility bias (Alreck and Settle, 1985). Interview data, was supplemented, however, with the author's knowledge of the area as well as non-participant observation of various tourism offerings over time (McCracken, 1988). Primary data was supplemented with secondary data from tourist brochures, festival and events guides, web-sites and policy documents. The study uses multiple sources of evidence as is consistent with a case study approach (Eisenhardt, 1989; Yin, 1993). The secondary data was used to validate accounts from the interviewees, identify rival accounts and distinguish between the intentions of policy makers and outcomes. It also gave precision to the interviews. Interviews were conducted in a semi-structured to open-ended manner. They lasted between 30 and 60 minutes.

Grounded theory emphasises the discovery of theory from data and research questions proceed from the broad to the more specific over time (Smircich and Stubbarrt, 1985). The researcher should be 'theoretically sensitised' (Miles and Huberman, 1994) but should avoid premature categorisation and remain open to the 
possibility of new or surprising findings. The grounded theory approach was adopted as it permits in-depth investigation of social phenomena and is most appropriate when the researcher seeks to understand "how" and "why" social behaviour occurs (Arnould and Wallendorf, 1994). Furthermore, Seo and Creed's (2002) model of change demands sensitivity to time and context which is a feature of grounded theory. Regarding data analysis, within-case analysis was carried out along the lines recommended by Eisenhardt (1989) and other experienced case-based researchers (Yin, 1993; Yin, 2003; Miles and Huberman, 1994). One of the major dangers of case study analysis is drawing premature conclusions (Eisenhardt, 1989) which can be countered by looking at the data in divergent ways. The procedure in the present study can be matched to Eisenhardt's (1989) set of steps for case study research. Table 3 summarises each of the procedures described by Eisenhardt (1989) and maps these to the present study. Analysis was around major themes or concepts highlighted in the literature, such as social entrepreneurs, their perceived contributions to cultural tourism development, the response of policy makers and any tensions between policy makers and social entrepreneurs.

\section{INSERT TABLE 3 HERE}

As regards limitations, this article is based on one case study so it is impossible to generalise and specify lessons for other tourist destinations. Yin (1993), however, does not see the single case study as a limitation since it generates a great richness of data. In contrast, Pettigrew (1989, p.1) argues for case study diversity, stating that "...it makes sense to choose cases such as extreme situations and polar types in which the process of interest is transparently observable". The lack of crosscase analysis is perhaps a weakness of this study. There is scope to study similar and dissimilar cases, with the latter being the fate of aboriginal languages and cultural tourism in Australia, and the former being the Welsh experience of ethnic tourism (Aitchison and Carter, 1999).

\section{Early development of the institutional field: government policy and the socio- economic development of the Gaeltacht}


The data findings suggest that the emergence of cultural tourism in the south-west of Ireland was the result of the interaction of three main forces: government policy, resource-mobilisation opportunities and social entrepreneurship. Figure 3 depicts the impetus for cultural tourism development. The obvious starting-point to cultural tourism development is the possession of cultural resources and in this article it is argued that social entrepreneurs kept this resource alive and paved the way for the slow erosion of old views which centred on how culture was all about the past with little value being placed on living culture.

The following section presents an overview of government policy in relation to the Gaeltacht from the 1960s to the present day. It is divided into two phases that are characterised by different norms, values and discourses.

INSERT FIGURE 3 HERE.

\subsection{Government policy: traditional industries, hard assets, heritage tourism and 'gazing on the past'}

Údarás na Gaeltachta was established in 1979 and it took responsibility for the economic development of the 'Gaeltacht', the Irish-speaking areas. In the late 1960s, policy makers supported the development of traditional, resource-based and homebased industries. There was an emphasis on foreign direct investment (Begley, Delany and O'Gorman, 2005), a policy labelled 'industrialisation-by-invitation' (Gottheil, 2003). Irish policy makers adopted the formula "no jobs, no people, no people, no Gaeltacht" (Williams, 1988: 279). According to the Regional Manager of Údarás na Gaeltachta, the area was a peripheral one in need of investment:

That manufacturing model, pattern or paradigm...had an impact: the Gaetacht went from a position of massive unemployment to a position where 8,500 people were employed in Gaeltacht areas, that was very significant for rural areas, areas that were underdeveloped and disenfranchised.

Despite significant interventions, scholars note that many projects failed to generate long-term growth in employment (Keane and O' Cinnéide, 1986; Ni Bhradaigh, 2007; O' Cinnéide and O' Conghaile, 1990). The goal of Údarás was to build a capacity for self-help in communities and transform an attitude of dependency 
into one of self-reliance (Keane and Ó Cinnéide, 1986). However, community enterprises had a high dependence on government subsidy and lacked competitiveness, defined as some combination of quality, uniqueness and competitive price. The severe disadvantages experienced by peripheral rural areas, compounded by high emigration rates, meant that 'an entrepreneurial spirit was slow to emerge' (Ni Bhradaigh, 2007: 277).

In the 1980s, policy makers seized upon heritage tourism as a form of rural regeneration. The growth rate of international tourism together with the availability of European Union (EU) funding for capital projects led to a flood of heritage and museum projects in Ireland (Beiner, 2005; Hurley et al., 1994; McGettigan and Burns, 2001; Stocks, 2000). Although the Irish state assumed the mantle of owner and operator of heritage, research suggests that some heritage sites were subject to market failure: government subsidy and earned income was not enough to ensure viability (Cooke, 2006).

The afore-mentioned policies were formulated in a period of high and intractable unemployment. Over a ten year period, Ireland's economy showed a remarkable turnaround. It went from being one the poorest regions in the EU in 1991 to having the second highest per capita GDP growth in 2001 (Walsh, 2004a). A variety of social, economic and political changes reshaped Ireland and the capacity for cultural tourism. The role of these contextual forces in shaping cultural tourism is discussed in the following section.

\subsection{Government policy: living culture, Irish language, festivals and cultural experiences}

Debates about the role of minority languages in socio-economic development and ways of arresting decline continue to preoccupy scholars (Grin, 2006; Aitchison and Carter, 1999; Pitchford, 1994). The Irish language was once associated with Ireland's colonial past and experience of victimization. Implicit within the modernising discourse is that minority languages are, "at best, an irrelevance, at worst, an obstacle to development" (Aitchison and Carter, 1999: 177). The work of 
Walsh (2004b) suggests that Údarás na Gaeltachta's strategy was infused with contradictions. The focus on large-scale, exogenous investment in the 1970s led to language erosion. Development was accompanied by declining percentages of Irish speakers, claims of a linguistic crisis and fears that much of the official Gaeltacht would become extinct (Walsh, 2004b; Johnson 1993). Scholars note that certain industrialisation practices weaken the language, as seen in the attraction of Englishlanguage call centres and influx of non-Irish speakers to the Gaeltacht (Ni Bhradaigh, 2007b; Coimisiún na Gaeltacht, 2002).

Today, Ireland's political commitment to maintaining the primacy of the Irish language is evident (see Coimisiún na Gaeltachta, 2002 for a review ${ }^{1}$ ). Language activists could be labelled 'intellectual elites', a Gaelic speaking bourgeoisie, who are able to influence the agenda of the policy makers and shape public opinion (Aitchison and Carter, 1999: 180). However, there is a wide gap between intentions and outcomes, between rhetoric and reality (Coimisiún na Gaeltachta, 2002; Hindley, 1990). Only $3 \%$ of the Irish population speak Irish on a daily basis (Government of Ireland, 2006).

Policy planners had to grapple with conflicting interests, between protecting Irish as a living language and developing tourism. Second-home or holiday home development has also been regarded as a key factor in reinvigorating rural economies. Opponents of this policy pointed to the intrusive nature of the development on the landscape and the low rate of occupancy. It drove property values out of reach of local residents (Kerry County Council, 2003; Norris and Winston, 2007). Furthermore, the policy of offering tax incentives for holiday home development was said to dilute the linguistic and cultural strengths of Gaeltacht areas (Denver, 2002; Coleman, 2003). Attempts were made to respond to negative public opinion about the housing market. In the Galway Gaeltacht, strict language-protection conditions were imposed on planning permissions (Ó Catháin, 2008). It follows that state officials were caught up in shifting power relations between property developers, locals and non-locals, who represented conflicting discourses.

Power struggles between language activists and tourism interests are evident in the controversy over signage. In 2005, the Irish Government passed the Place- 
names Order. This act required direction signs in the Gaeltacht to be in Irish only to signify that Irish is a living language and that the area is culturally distinctive (Department of Arts, Heritage, Gaeltacht and the Islands, 2000). This move antagonised some residents, to the extent that signs were vandalised. In Dingle, a major tourist town, opposition was based on the fact that tourists would be unable to interpret the signs, and that people's sense of place was being sacrificed to indulge cultural purists. A compromise was eventually reached, with the use of bilingual signage. $^{2}$

There is some evidence in the academic literature that a minority language is linked to regional economic development, although linkages are highly complex (McLeod, 2002; Chalmers, 2003). While languages that are diffuse - not unique to one state - are seen as fragile (White, 1991), the existence of an Irish Diaspora provides fodder for cultural tourism strategies. Gaelic cultural resources, directed at external markets, are now perceived to play a role in the regeneration of rural areas. According to the Regional Manager of Údarás na Gaeltachta, "you can cherish the language but also manage it rigorously as a commercial resource". He explained how this could happen though the clustering of activities:

So a visitor could buy a week in Kerry, pick-and-mix, celebrate local culture, go on a hill-walk, do a cookery course, go horse-riding, fishing, do a course in archaeology, be introduced to local cultural traditions...these packages can be provided 'as Gaelige'. Instead of spending a week sitting in a classroom learning Irish, people can do activities through Irish, in Irish and gain exposure to Irish. Cultural tourism can become a package but anchored down in the language (Regional Manager, 2007)

From 1996 to 2006, Údarás refocused on the socio-cultural development of the Gaeltacht and $20 \%$ of capital expenditure is devoted to language-based projects. Cultural tourism, which draws the well-educated, high-spending tourist, is seen as a viable strategy for communities in the Gaeltacht (Údarás na Gaeltachta, 2005; 2007). A new branding campaign, Gael-Saoire (Holidays in the Ghaeltacht) was launched in 1997 in order to differentiate the Gaeltacht from other tourist destinations. However, the lack of product on the ground, along with the declining number of Irish speakers and lack of opportunity for visitors to practice their Irish in a social setting (Convery and Flanagan, 1996), proved to be barriers to success. 
The 1990s represented an era of change in the official promotion of Irish tourism. Marketing campaigns sought to capitalise on Ireland's fashionable image and success in music, literature, theatre, film and dance (Prentice and Anderson, 2000). Irish Tourism attempted to present Ireland "not so much as a place to see but as a place to experience, combining its historical features with more contemporary ones" (Johnson, 1999: 191). This represented an organic expansion of heritage tourism, a move away from the 'gazing on the past' (Urry, 1990). The success of Riverdance $^{3}$, international rock artists, along with Guinness and the Irish pub, acted as a signifier of Ireland's national myths and stereotypes, shaped tourists' expectations and re-enforced the conception of Ireland as a musical nation (Nicholls, 2000; Ó' Cinnéide, 2005; Strachan and Leonard, 2004). It could be argued that this new-found cultural confidence facilitated the development of cultural services and products.

Festival tourism was seen as a tool to spread tourism consumption geographically and extend the tourist season (Fáilte Ireland, 2007a; Quinn, 2006; Convery and Flanagan, 1996). There was, however, some resistance to change. According to one respondent in Fáilte Ireland, most of her colleagues were unsure about the economic benefits of cultural tourism, a niche market (Manager, Fáilte Ireland). She remarked that the mentality "was all about golf" - tourist products that combined quantity and quality and appealed to the North American and European markets. It is important to note that different types of tourism can co-exist, e.g. golf and arts tourism in the Gaeltacht. Another individual remarked that the reluctance to embrace the arts in tourism stemmed from false perceptions - the notion that the arts were "somewhat elitist or exclusive" in nature (Arts Consultant, 2007).

In summary, the picture that emerges of Irish tourism development is a complex one. It has expanded from heritage tourism to cultural tourism, from recycling the past to an orientation towards the present. The emergence of language-based tourism reflects, to some degree, changing power structures within the country and resurrection of status to a minority language. Evaluation of government policy reveals many shortcomings, uncertainties and contradictions: the promotion of language tourism and the falling numbers of Irish speakers, the appropriation of culture for a 
global tourist audience and the globalisation of the Irish economy. The following section describes how the development of cultural tourism was influenced by social entrepreneurship.

\section{Social (or community-based) entrepreneurship}

Social enterprise is manifested in the efforts of intellectual elites to protect the rights of a minority language group, as well as the attempts by residents in the Gaeltacht to sustain, and capitalise on, their cultural traditions. The rise of community festivals also helped develop the market for cultural tourism.

\subsection{Social enterprises: promoting a minority language}

Research has shown that Ireland has a long tradition of social enterprise (Ni Bhradaigh, 2007; O’Hara, 2001). For instance, there was significant church involvement in the provision of services such as health, education and welfare (O'Hara, 2001). Community-based enterprises played a pivotal role in the socioeconomic development of the Gaeltacht (Keane and O' Cinnéide, 1986; O' Cinnéide and Conghaile, 1990). The cooperative sector sowed the seeds for the establishment of the Irish language radio and television stations (Coleman, 2003). This initiative was planned, not as a measure to revive Irish as a community language, but on the basis of minority rights. The launch of an Irish language television station, TnaG, in 1996, was preceded by hostile media coverage, where the project was called into question, mainly on the basis that it was a waste of money to build a new television channel for the small number of people who spoke Irish. However, it went on to become a successful niche broadcaster (Corcoran, 2004: 185).

Summer schools, the Coláiste Samhraigh, have been in existence since the late 1960s. They constitute an informal means of language education whereby secondary school students spend time in the Gaeltacht in order to improve their oral Irish skills. According to the Regional Manager of Údarás na Gaeltachta,, “...the Coláiste Samhraigh and the and the bean an tí ${ }^{4}$ have been around for the last 30 years and is part of the cultural tourism infrastructure, even though it was never called cultural tourism". In the Kerry Gaeltacht, the summer schools were a village-based initiative 
where women's domestic skills and language fluency were used to earn income. The success of the summer schools had a catalytic effect on policy makers, and showed that language can serve as an engine for local economic development. Capital grants was made available by the state and the schools attracted 25,000 young people in 2006 (Department of Rural, Community and Gaeltacht Affairs, 2007).

Other examples of community-based enterprises in the case study region include Diseart, an educational institute specialising in Irish culture. The Great Blasket Island Forum is a good example of a community organisation. The island once sustained a vibrant oral Irish culture and inspired an impressive vernacular literature (Beiner, 2005). Emigration left it without people and it was offered for sale in 1987. This shocked the local community who feared that the traditional setting and meaning of the Island would be lost. Subsequently a local community group sought to reclaim the island as a National Historic Park and are also seeking World Heritage Site Status for it (Manager, Great Blasket Island Interpretative Centre, 2007). This case conveys the sense of a power struggle, when corporate interests collided with the interests of a minority language group.

\subsection{Social enterprises: developing traditional Irish music}

Comhaltas Ceoltóirí Éireann (CCE) played an important role in popularising Irish music. It can be seen as a social enterprise since it is a not for profit organisation, it relies on volunteer labour, and its mission is to promote the traditional arts. It was founded in 1951 at a time when the traditional arts were neglected. Today, the Irish Diaspora has created a new audience for Irish culture (Kearns and Taylor, 2003; Smith, 2001). Kneafsey (2002) points to the increasing pace of life and commercialisation of societies to explain the growing interest in traditional music, as people search for 'authenticity'. These developments tended to boost the overall prestige of Irish music and demand for Gaelic cultural products.

CCE established numerous branches for music education in Ireland and overseas, and it relied heavily on amateur musicians who passed on their love of music to the younger generation. CCE is known for hosting the feis cheoil, or music festival, which includes performances, music and dance competitions (Fleming, 
2004). The traditional music sector in Ireland has been characterised by schisms and tensions. Debates about Comhaltas Ceolteoiri Éireann (CCE) revolved around fears about music standardization, loss of musical diversity and a lack of control over how traditional music is publicly portrayed (Fleming, 2004). To some musicians, competition and standardisation of playing techniques is anathema and transmission, the passing on of local style and repertoire, lies at the heart of traditional music (Kearns and Taylor, 2003). These cultural conflicts spurred the growth in community-based festivals, such as the Willie Clancy Summer School (which was established in 1973) and the World Bodhrán Festival. The vision of the founders was to raise standards of practice and provide musicians with an alternative to competition-based performances.

In recent times, more resources have been channelled towards the traditional arts. In the 2000s, the Minister for the Arts established a new organisation, Culture Ireland, to generate awareness of Irish art and culture on an international level and facilitate policy formation and coordination. For this reason, it is argued that the new institutional field, cultural tourism, has achieved legitimacy.

\section{Resource mobilisation opportunities}

Údarás has a long standing policy of funding organisations and projects that create jobs based on Gaelic culture. Over time, there was a growing awareness that development had to be 'bottom-up' and based primarily on local strengths and values (O’Cinneide and Keane, 1990).

Some examples of innovation include Cill Rialaig: it functions as a co-operative venture between Údarás na Gaeltachta and the local community. The project involved the refurbishment of traditional houses and a pre-famine village as a retreat for artists in the 1980s (McCarthy, 2008). The Kerry GeoPark initiative emerged out of the belief that the landscape, local foods, arts and culture have the potential to attract the independent traveller, increase bed-nights and counteract leakage (McCarthy, 2009). 


\section{Institutional change: application of Seo and Creed's (2002) framework to cultural tourism}

This article is concerned with addressing the origins of cultural tourism, how it was constructed by different stakeholders and how conceptualisations changed over time. The study points to two important issues: the role of conflict amongst actors, and in particular, the role of social entrepreneurs in shaping the development of new fields. To examine this, the Seo and Creed framework is applied to the context of cultural tourism policy in Ireland. This is illustrated in Figure 4.

\section{INSERT FIGURE 4 HERE}

Beginning with the element of institutions in the framework, it is frequently argued that institutions are sometimes hard to change because of path dependency (North, 1990; Powell, 1991). As regards the Gaeltacht, path dependency can be observed in the focus on economic development. Seo and Creed (2002) also show how underlying contradictions or tensions between institutions become a force for change. The ongoing experience of contradiction reshapes the consciousness of institutional members, and they, in some circumstances, act to fundamentally transform social arrangements and themselves (praxis). In this analysis, Údarás na Gaeltachta appeared to incorporate incompatible practices in their pursuit of economic development. For example, industrialisation in the 1970s undermined the language and in recent times holiday home development attracted vocal critics. The literature indicates that the development of a new field is likely to be rife with conflict (Aldrich and Fiol, 1994; Di Maggio, 1991, Lawrence, 1999); one explanation is that actors use multiple logics, ideologies or beliefs (DiMaggio and Powell, 1991) and different ideologies illustrate competing interests, contradictions and incompatibility. This study showed some evidence of tensions where one ideology was pitted against another. For instance, tourism development versus language development; standardisation of music versus diversity of musical traditions; commodification of culture versus preservation of culture for locals. There was some evidence of disincentives associated with entrepreneurship. The potential to gain from culture and 
not contribute, to start new ventures by hanging on to the coattails of Irish culture, was a source of tension between festival organisers and policy makers.

Social entrepreneurship was revealed by the emergence of cultural associations, community festivals, language activists and the Coláiste Samhraigh. Social entrepreneurs, who included intellectual elites lobbying for protection of the Irish language, served to influence policy makers in two ways, positively, by providing opportunities for continued learning and change, by reducing uncertainty and demonstrating the economic viability of cultural ventures; negatively, as regards legitimacy and sanctions such as withdrawal of community support and risk of a tarnished reputation. Local actors have expectations and were responsible for serious questioning of policy and adjustments followed such as new land-use policies in the Gaeltacht, promotion of living culture and language-based tourism. Conflicts within cultural associations such as Comhaltas Ceoltóirí Éireann spurred the development of informal music festivals and influenced consumer demand. Conflict co-existed with attempts at collaboration and this generated challenges for both sides, but also opportunities for learning and change. Seo and Creed (2002) argue that contradictions are the fundamental driving force of institutional change. They propose that there are four sources of contradictions which are as follows: misaligned interests; interinstitutional incompatibility, non adaptability and inefficiency. Under these conditions institutional change is likely to occur. Some of these features were evident in this study. Inefficiency and non-adaptability was evident when policy and regulation failed to offset the loss of manufacturing industry. The focus on development could be labelled 'isomorphism' since Údaras acted like other development agencies, notably Shannon Development or Enterprise Ireland, and prioritized investment in 'hard', tangible assets.

Over time, living culture moved from the periphery to the core of tourism strategy. Social entrepreneurs, by promoting the socio-economic role of culture in regional development, helped bring about major changes in orientation amongst policy makers. Contextual factors, the economic boom, pride in the achievements of Irish artists, debates about language rights and the nature of tourism in academic circles, the rise in international tourism, were also important. Anderson (2000) argues that peripherality can become an asset when it results in the preservation of social and 
cultural resources and traditions that have been swept away by development in the centre. Benneworth (2004: 453) notes that, 'tradition' plays an important role in the in the periphery, preventing local assets from being stripped out by external agents. In the rural tourism literature, there is evidence that the 'otherness' of a peripheral region supports rural branding and rural tourism (Cai, 2002). Maintaining a balance between the cultural and economic, cashing in a tourist boom while preserving a traditional way of life is a dilemma faced by many tourist destinations (Taylor, 2001; Richards, 2001).

Seo and Creed (2002) conclude that change is driven by institutional participants whose interests are not adequately served by the existing arrangements. They note that marginalised groups play an important role in the change process. Similarly, Battilana (2006) notes that peripheral, or lower-status, organisations tend to challenge the status quo. Gaelic language was, for a long time, seen as a break or depressant on regional economic development (McLeod, 2002). While the Irishspeaking community and the traditional arts were marginalised, in modern times the language has received a considerable degree of institutional support, for example, in education, under the Irish constitution and in public administration.

The study reinforces the point that to think of institutional change as constituting simple movements from one optimal position to another is flawed and misleading (Burns and Scapens, 2000). To do so, would be to ignore the cumulative nature of change where context, history, institutional embeddedness and transformational agency all matter (Burns and Nielsen, 2006). The study reinforces the need to provide a more critical framework for the study of tourism and to locate cultural tourism in the wider social, economic and political systems. The construction of cultural tourism was shown to be uncertain and the strategies pursued by policy makers were more 'emergent' than 'intended' (Mintzberg and Waters, 1985) where policy makers had to adapt to failed strategies and respond to the needs of social and community-based entrepreneurs.

\section{Conclusion: role of social entrepreneurs in the development of a new institutional field}


This article is interested in exploring if, and how, social entrepreneurs subvert institutions. The answer may lie in the increasing cultural acceptance, and economic performance or contribution, of social entrepreneurs. This article began by describing new institutional theory and social entrepreneurship and concludes that both are relevant theoretical lenses to explain the emergence of a new field of activity, cultural tourism. The article drew on Seo and Creed's (2002) model of institutional change, along with empirical evidence, for explaining when, why and how local actors, specifically, social entrepreneurs, influenced government policy and shaped the construction of cultural tourism. Current ideas about cultural tourism include the celebration of living culture, an emphasis on language, festivals and music and the recognition that the community, rather than the state, is the repository of culture. This article concludes that the state does not necessarily have superior ability to identify a better future for local economies; rather continuous interactions between policy makers, academics, practitioners and social entrepreneurs shaped the construction of cultural tourism. Cultural tourism is a dynamic process where different stakeholders with convergent and divergent interests intersect, and options are debated before particular policies are adopted. The article illustrates that a new institutional field is shaped by a nexus of global and local forces, which together, help inject new ideas into domestic debates on cultural tourism and ways to stimulate economic development.

\section{Acknowledgements}

Thanks to the anonymous referees for their invaluable comments on previous drafts of this article. I would like to thank Fáilte Ireland for helping me obtain relevant primary information. This article was part of a larger study exploring the drivers and barriers to cultural tourism in the south-west of Ireland which was funded by Fáilte Ireland under its Research Fellowship scheme 2006/7.

\section{References}

Aitchison, J. and Carter, H., 1999. Cultural empowerment and language shift in Wales. Journal of Economic and Social Geography 90, 2: 168-183.

Aldrich, H.E., and Fiol, C.M. 1994. Fools rush in: the institutional context of industry creation. Academy of Management Review 19: 645-70. 
Alipour, H., and Kilic, H. 2003. An institutional appraisal of tourism development and planning: the case of the Turkish Republic of North Cyprus (TRNC). Tourism Management 26, 1: 79-94.

Alreck, P., and Settle, R. 1985. The survey research handbook. Homewood: Irwin

Anderson, A. 2000. Paradox in the periphery: An entrepreneurial construction.

Entrepreneurship and Regional Development 12 (2): 91-109.

Arnould, E.J. and Wallendorf, M. 1994. Market Oriented Ethnography: Interpretation Building and Marketing Strategy Formulation. Journal of Marketing Research 31 (November): 484-504.

Arts Consultant, 2007. Personal Communication.

Barley, S.R and Tolbert, P.S. 1987. Institutionalization and structuration: studying the links between action and institution. Organization Studies 18 (1): 93-117.

Battilana, J. 2006. Agency and Institutions: the Role Enabling Role of Individuals' Social Position. Organisation 13 (5): 653-676.

Begley, T., Delany, E., and O'Gorman, C. 2005. Ireland at a Crossroads: still a Magnet for Corporate Investment? Organisational Dynamics 34 (3): 202-217.

Beiner, G. 2005. Commemorative heritage and the Dialetics of Memory in Ireland's Heritages: Critical Perspectives on Memory and Identity M. McCarthy (Ed), Dublin: Ashgate Publishing.

Benneworth, P. 2004. In what sense 'regional development': Entrepreneurship, underdevelopment, and strong tradition in the periphery. Entrepreneurship and Regional Development 16(6): 439-458.

Burns, J., and Nielsen, K. 2006. How do embedded agents engage in institutional change? Journal of Economic Issues 2: 449-456. 
Burns, J., and Scapens, R. 2000. Conceptualizing management accounting change: an institutional framework. Management Accounting Research 11 (1): 3-25

Cai, L., 2002. Cooperative Branding for Rural Destinations. Annals of Tourism Research, 29(3): 720-742.

Chambers, D. 2003 Economic impact of Gaelic arts and culture. PhD thesis, Glasgow: Caledonian University

Chell, E. 2007. Social Enterprise and Entrepreneurship: Towards a Convergent Theory of the Entrepreneurial Process. International Small Business Journal 25 (1): 5-26.

Cohen, E. 1988. Authenticity and Commoditization in Tourism. Annals of Tourism Research, 15 (3): 371-86.

Coimisiún na Gaeltachta 2002. Report of the Gaeltacht Commission. Available at: http://www.pobail.ie/en/AnGhaeltacht/ReportoftheGaeltachtCommission (retrieved March 14, 2006)

Cooke, P. 2006. Building a partnership model to manage Irish heritage: a policy tools analysis. Irish Journal of Management, 27 (2): 75-97.

Coleman, S. 2003. Community, language and culture in C. Coulter and S. Coleman (eds) The End of Irish History (pp. 175-191). Manchester: Manchester University Press.

Convery, F., and Flanagan, S. 1996. From the Bottom Up: a Tourism Strategy for the Gaeltacht. An Daingean: An Sagart.

Corcoran, F. J. 2004. RTE் and the Globalisation of Irish Television Bristol: Intellect Books. 
Department of Arts, Heritage, Gaeltacht and the Islands. 2000. Annual Report 2000: Dublin: Dublin Stationary Office

Department of Rural, Community and Gaeltacht Affairs. 2007. Agreed Program for Government Progress Report. Dublin: Dublin Stationary Office.

Denver, G. 2002. The Linguistic Implications of Mass Tourism in Gaeltacht Area. New Hibernia Review 6 (3):23-43.

DiMaggio, P. 1988. Interest and Agency in Institutional Theory. In L.G. Zucker (Ed.), Institutional Patterns and Organizations: Culture and Environment (pp. 3-22). Ballinger: Cambridge: MA.

Di Maggio, P.J. 1991. Constructing an Organizational Field as a Professional Project: U.S. Art Museums, 1920-1940 in W.W. Powell and P.J. DiMaggio (eds) The New Institutionalism in Organizational Analysis (pp. 267-92) Chicago: University of Chicago Press.

DiMaggio, P., and Powell, W. 1983. The Iron Cage revisited: Institutional isomorphism and collective rationality in organizational fields. American Sociological Review 48: 147-160.

DiMaggio, P., and Powell, W. 1991. Introduction. In WW Powell and PJ DiMaggio (Eds.) The New Institutionalism in Organisational Analysis (pp 1-38). Chicago: University of Chicago Press.

Dorado, S., 2005. Institutional entrepreneurship, partaking and convening Organization Studies 26 (3): 385-414

Eisenhardt, K.M. 1989. Building theory from case study research. Academy of Management Review 14: 532-550.

Evers, A., and Schulze-Böing, M. 1997. Mobilising Social Capital: The Contribution of Social Enterprises to Strategies against Unemployment and Social Exclusion. 
Article presented at the EU Research Network EMES - the Emergence of Social Enterprises, Barcelona.

Fáilte Ireland 2005. Domestic Tourism Facts. Dublin: Fáilte Ireland.

Fáilte Ireland 2007. Personal communication with the Festivals and Events Officer and Product Management Officer.

Fáilte Ireland 2007a. Cultural Tourism: Making it Work for You - A New Strategy for Cultural Tourism in Ireland [Online]. Available: http://www.failteireland.ie/Developing-Markets/Product-Marketing/CulturalTourism (last accessed 12 August 2009).

Fernández-Alles, M., and Valle-Cabrera, R. 2006. Reconciling institutional theory with organizational theories: how newinstitutionalism reconciles five paradoxes Journal of Organizational Change Management 19 (4): 503-517.

Fleming, R. 2004. Resisting Cultural Standardization: Comhaltas Ceoltóirí Éireann and the Revitalization of Traditional Music in Ireland. Journal of Folklore Research 41 (2/3): 227-257.

Friedman, V., and Desivilya, H. 2010. Integrating social entrepreneurship and conflict engagement for regional development in divided societies. Journal of Entrepreneurship \& Regional Development 22 (6): 495 - 514.

Getz, D. 1991. Festivals, special events and tourism. Van Nostrand Reinhold.

Gibson, C., and Connell, J. 2003. On the Road Again: Music and Tourism. Clevedon: Channel View Press.

Giddens, A. 1984. The Constitution of Society. Berkeley: University of California Press.

Glaser, B.G., and Strauss, A.L. 1967. The Discovery and Grounded Theory: Strategies for Qualitative Research. New York: Aldine. 
Gottheil, F. 2003. Ireland: what's Celtic about the Celtic Tiger. The Quarterly Review of Economics and Finance, 43 (5): 720-737.

Government of Ireland (2006) Statement of the Irish Language. Dublin: Stationary Office.

Great Blasket Island Interpretative Centre, 2007. Personal Communication with Manager.

Greenwood, R., and Hinings, C.R. 1996. Understanding Radical Organizational Change: Bringing together old and new institutionalism Academy of Management Review 21 (4): 1022-43.

Grin, F. 2006. Promoting language through the economy: competing paradigms Article presented at the $6^{\text {th }}$ Language and Politics Symposium: Economic Development and Language in Scotland and Ireland, Queen's University, Belfast, August 2006.

Ha-Joon, C. 1994. State, Institutions and Structural Change. Structural Change and Economic Dynamics 5 (1): 293-313.

Hindley, R. 1990. The Death of the Irish Language. Routledge, Chapman and Hall.

Hurley, A., Archer, B., and Fletcher, J. 1994. The economic impact of European Community grants for tourism in the Republic of Ireland. Tourism Management 15 (3), 203-211.

Johnson, N. 1993. Building a nation: an examination of the Irish Gaeltacht: Commission Report of 1926. Journal of Historical Geography 19 (2): 157-168.

Johnson, N. 1999. Framing the past: time, space and the politics of heritage tourism in Ireland. Political Geography 18 (2):187-207.

Kalantaridis, C. 2007. Institutional Change in Post-Socialist Regimes: Public Policy and Beyond. Journal of Economic Issues 2: 435-442. 
Keane, M., and Ó' Cinnéide, M. 1986. Promoting Economic Development amongst Rural Communities Journal of Rural Studies 2 (4): 281-289.

Kearns, T., and Taylor, B. 2003. A Touchstone for the Tradition: The Willie Clancy Summer School. Dingle: Brandon Publications.

Kerry County Council 2003. An Daingean: Local Area Plan. Kerry: Kerry County Council. Available at: http://www.kerrycoco.ie/planning/dingelintro.asp (retrieved May 2, 2006)

Kerry County Council 2009. Kerry County Development Plan 2009 to 2015 [Online] Available on line at http://www.kerrycoco.ie/en/allservices/planning/planspolicies/countydevelop mentplan2009-2015/thefile,2473,en.pdf (retrieved August 12 ${ }^{\text {th }}, 2009$ ).

Kerry County Development Board 2004. County Kerry Tourism Research. Kerry:

Economic Review Group, Kerry County Council. Available at:

http://www.kerrycdb.ie/tourism.asp (retrieved March 14, 2006)

Kennelly, K., and Dwyer, N. 2000 Guide to the Arts in Kerry. Kerry County Council. Available at http://www.kerrycoco.ie (retrieved February, 2006)

Kneafsey, M. 2002. Cultural geographies in practice: sessions and gigs: tourism and traditional music in North Mayo, Ireland. Cultural Geographics 9: 354-358.

Koene, B. 2006. Situated human agency, institutional entrepreneurship and institutional change. Journal of Organisational Change Management, 19 (3): 365-382.

Lawrence, T.B. 1999. Institutional Strategy. Journal of Management 25: 161-87.

Lawrence, T., and Phillips, N., 2004. From Moby Dick to Free Willy: Macro-Cultural Discourse and Institutional Entrepreneurship in Emerging Institutional Fields Organisation, 11 (5):689-711. 
Lounsbury, M. and Ventresca, M.J. and Hirsch, P.M. 2003. Social movements, field frames and industry emergence: a cultural-political perspective on US recycling. Socio-Economic Review 1: 71-104.

Lounsbury, M. and Ventresca, M.J. 2003. The New Structuralism in Organisational Theory. Organisation 10 (3), 457-480.

Mair, J., and Martí, I. 2006. Social entrepreneurship research: a source of explanation, prediction, and delight. Journal of World Business 41: 36-44.

Meyer, J., and Rowan, B. 1977. Institutionalised organizations: formal structure as myth and ceremony American Journal of Sociology 83: 340-363

McCarthy, B. 2008. Case Study of an Artists' Retreat in Ireland: An Exploration of its Business Model. Social Enterprise Journal 4 (2): 136-148

McCarthy, B. 2009. The Kerry GeoPark. European Council for Small Business: Case Study Competition 2009.

McCracken, G. 1988. The Long Interview. Newbury Park CA: Sage Publications

McGettigan, F., and Burns, K. 2001. Clonmacnoise: a monastic site, burial ground and tourist attraction in G. Richards (Ed) Cultural Attractions and European Tourism The Netherlands: CABI Publishing.

McLeod, W. 2002. Language planning as regional development? The growth of the Gaelic Economy. Scottish Affairs, 38, 51-72

Miles, M. and Huberman, A. 1994. Data Management and Analysis Methods in NK Denzin and Y.S. Lincoln (Eds.) Handbook of Qualitative Research (pp. 428444) Thousand Oaks, CA: Sage.

Minister for the Arts, 2007. Personal Communication. 
Mintzberg, H. and Waters, J. 1985. Of strategies, deliberate and emergent. Strategic Management Journal, 6: 257-72.

Mohr, J.W. and Guerra-Pearson, F. 2009. The Differentiation of Institutional Space: Organizational forms in the New York Social Welfare Sector 1888-1917, in W.W. Powell and D. Jones (Eds) How Institutions Change Chicago: University of Chicago Press.

Ni Bhradaigh, E. 2007. The overlooked rugged communitarians of Ireland. Journal of Enterprising Communities, People and Places in the Global Economy 1 (2): 155-161.

Ni Bhradaigh, E. 2007a. Sure weren't we always self-sufficient didn't we have to be! Entrepreneurship in the Gaeltacht of Ireland in L.P. Dana, \& R.B. Anderson (Eds), International Handbook of Research on Indigenous Entrepreneurship Cheltenhan: Edward Elgar Publishing

Nicholls, J. 2000. Introduction. In J. Nicholls and S.J. Owens (Eds) A Babel of Bottles. Drink, Drinkers and Drinking Places in Literature (pp 9-20) Sheffield: Sheffield Academic Press

Norris, M., and Winston, N. 2007 Second homes in scenic rural areas of Ireland: preliminary results from a study of social, economic and environmental impacts. In: Conference Proceedings, European Network for Housing Research ENHR International Conference: Sustainable Urban Areas, 25-28 June, Delft University of Technology, Rotterdam.

North, D.C. 1990. Institutions, institutional change and economic performance New York: Cambridge University Press.

O’Catháin, M. 2008. No sale housing clauses are no joke, Galway Advertiser, January $7^{\text {th }}, 2008$. 
O'Cinnéide, B. 2005. Creative entrepreneurship in the arts. Entrepreneurship and Innovation 6 (3): 151-158.

O’Cinnéide, M., and Conghaile, M. 1990. Promoting Local Initiative through a Community Development Competition Journal of Rural Studies, 6 (3): 325-329.

O’Cinnéide, M., and Keane, M. 1990. Applying strategic planning to local economic development: the case of the Connemara Gaeltacht, Ireland The Town Planning Review, 61(4): 475-486.

O’Hara, P. 2001. Social Enterprise \& Local Development in C. Borzaga and J. Defourney (Eds) The Emergence of Social Enterprise Routledge: London

Organisation for Economic Cooperation and Development. 1999. Social Enterprises Paris: OECD Publications.

Pearce, D. 1987. Tourism Today: A Geographical Analysis. Harlow: Longman Scientific and Technical

Peredo, A., and McLean, M. 2006. Social Entrepreneurship: A Critical Review of the Concept. Journal of World Business 41: 56-65.

Pettigrew, A. 1989. Longitudinal Field Research on Change: Theory and Practice in R.M. Mansfied (Ed.) New Frontiers in Management (pp 21-49). London: Routledge

Pitchford, S. 1994 Ethnic tourism and nationalism in Wales. Annals of Tourism Research, 21 (3): 35-50.

Pritchard, A., and Morgan, N. 2001. Culture, identity and tourism representation: marketing Cymru or Wales? Tourism Management 22: 167-179 
Powell, W. 1991. Expanding the Scope of Institutional Analysis. In WW Powell and PJ DiMaggio (Eds.) The New Institutionalism in Organisational Analysis (pp 183-203). Chicago: University of Chicago Press.

Prentice, R. 1993. Tourism and Heritage Attractions. London: Routledge.

Prentice, R., and Anderson, V. 2000. Evoking Ireland: Modelling Tourism Propensity. Annals of Tourism Research 27 (2): 490-516

Putnam, R. 1993. Making Democracy Work - Civic Traditions in Modern Italy. Princeton, New Jersey: Princetown University Press

Quinn, B. 2006. Problematising Festival Tourism:Arts Festivals and Sustainable Development in Ireland. Journal of Sustainable Tourism 14 (3): 288-306.

Richards, G. 1994. Cultural Tourism in Europe New York: CAB International.

Richards, G. 1996. Production and consumption of European Cultural Tourism. Annals of Tourism Research, 23 (2): 261-283.

Richards, G. 2001. The Development of Cultural Tourism in Europe in G. Richards (ed) Cultural Attractions and European Tourism (pp. 3-31). UK: CABI International

Scott, W. 2001. Institutions and Organisations. Thousands Oaks, CA: Sage.

Seo, M., and Creed-Douglas, W. 2002. Institutional Contradictions, Praxis and Institutional Change: A Dialectical Perspective. Academy of Management Review 27 (2): 222-247.

Smith, S. 2001. Irish Traditional Music in a Modern World. New Hibernia Review 5, (2): 111-125.

Smircich, L., and Stubbart, C. 1985. Strategic Management in An Enacted World. Academy of Management Journal 10 (4): 724-736. 
Strachan, R., and Leonard, M. 2004. A Musical National: Protection, Investment and Branding in the Irish Music Industry. Irish Studies Review 12 (1): 39-49.

Stocks, J. 2000. Cultural tourism and the community in rural Ireland in D. Hall and G. Richards (eds) Tourism and Sustainable Community Development Routledge: Advances in Tourism Research.

Taylor, J. 2001. Authenticity and Sincerity in Tourism, Annals of Tourism Research, 28 (1): 7-26.

Tolbert, P.S., and Zucker, L. G. 1983. Institutional sources of change in the formal structure of organisations: the diffusion of civil service reform 1980-1935. Administrative Science Quarterly 28: 22-39.

Údarás na Gaeltachta 2005. Strategic Development Plan 2005-2010. Galway: Údarás na Gaeltachta. Available on http://www.udaras.ie/index.php/corporate_menu/publications/1123 (retrieved April 10, 2006)

Údarás na Gaeltachta 2007. Tourism Strategy 2007 - 2010. Galway: Údarás na Gaeltachta

Údarás na Gaeltachta 2007 Personal Communication with Regional Manager

Urry, J. 1990. The Tourist Gaze London: Sage.

Walsh, J. 2004a. Planning for Regional Development in a Peripheral Open Economy - the Case of Ireland. In R. Bryon, J.C. Hansen and T. Jenkins (eds) Regional Development on the North Atlantic Margin England: Ashgate Publishing.

Walsh, J. 2004b. Language, culture and development: the Gaeltacht Commissions 1926 and 2002. Working Article Dublin: Dublin City University.

White, P. (1991) Geographical aspects of minority language situations in Italy. In C.H. Williams (ed) Linguistic Minorities, Society and Territory. Clevedon, Avon: Multilingual Matters. 
Williams, C.H. 1988. Language planning and regional development: lessons from the Irish Gaeltacht in C.H Williams (ed) Language in Geographic Context. Clevedon, Avon: Multilingual Matters

Yin, R.K. 1993. Applications of Case Study Research London: Sage Publications.

Yin, R.K. 2003 Case Study Research: Design and Methods Thousand Oaks: Sage Publications.

Zeppel, H., and Hall, C.M. 1991. Selling art and history: cultural heritage and tourism. The Journal of Tourism Studies 2 (1): 29-44. 


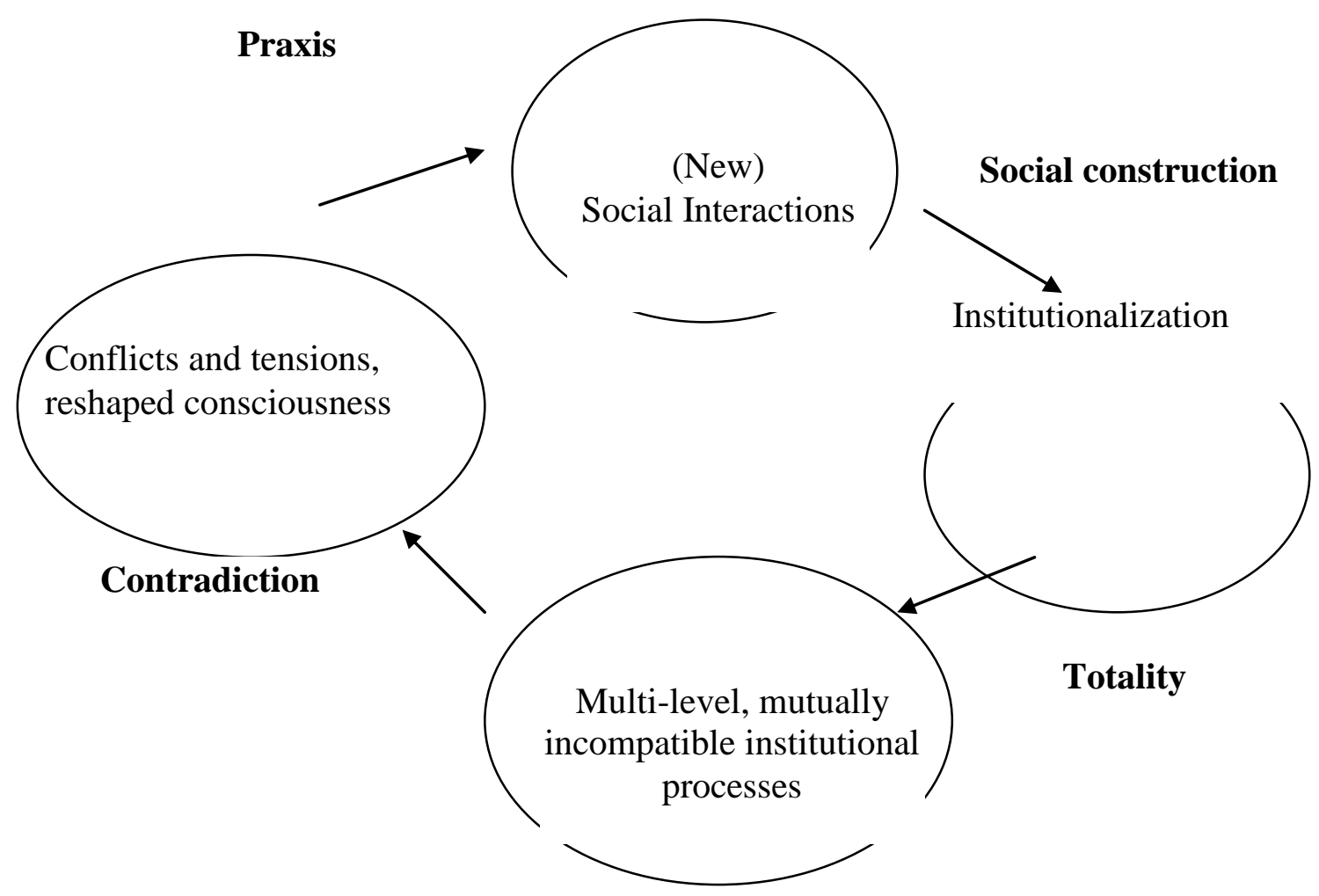

Figure 1: Institutionalization and Institutional Change: Processes from a Dialectical Perspective (Seo and Creed, 2002) 


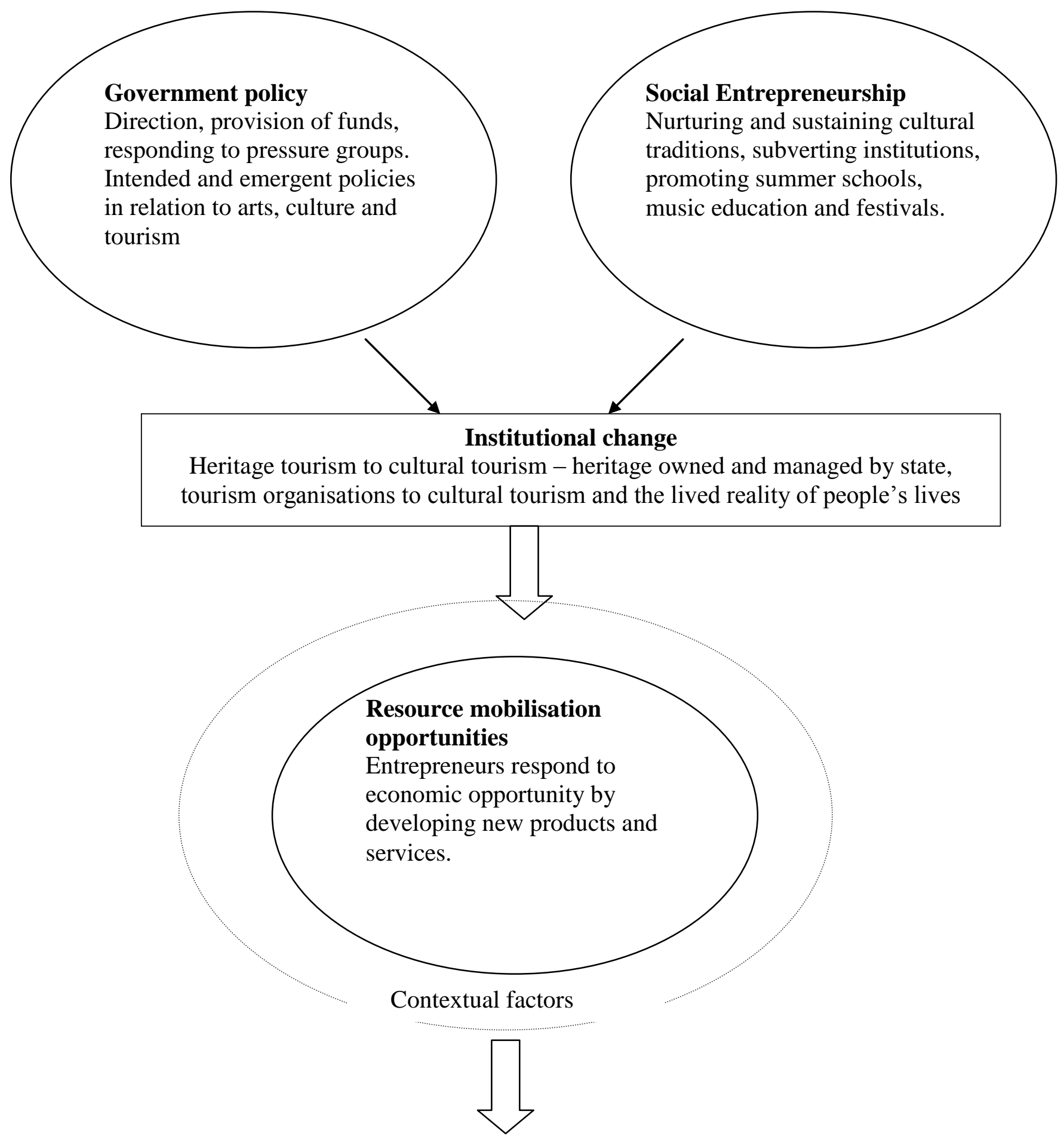

Outcomes: local economic development, better quality of life, improved tourist experience

Figure 3: A summary view of three key factors affecting the formation of a new institutional field: cultural tourism 
Politicians, policy makers, local residents, entrepreneurs \& academics

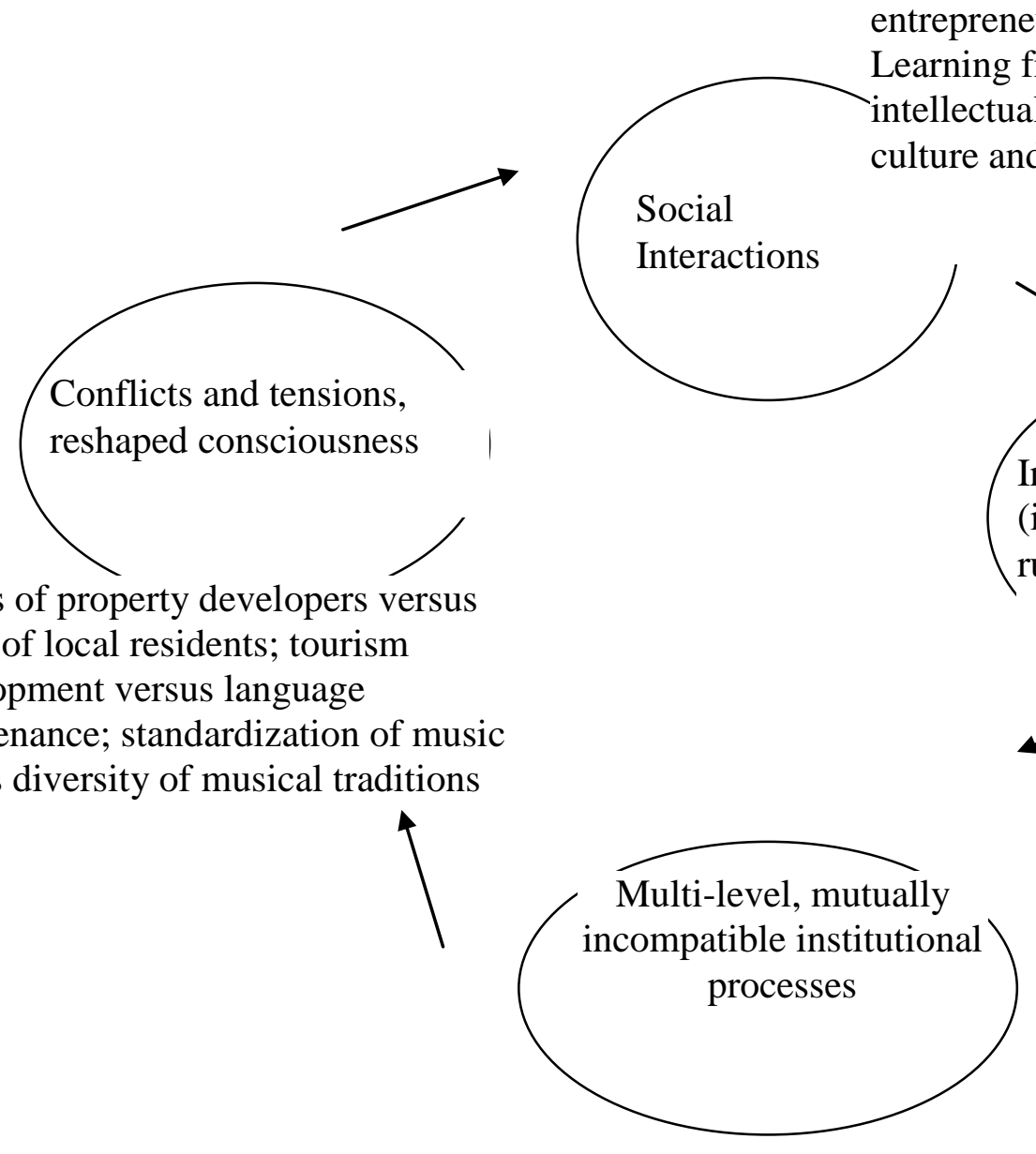

Economic development versus survival of the Irish language
Rights of property developers versus rights of local residents; tourism development versus language maintenance; standardization of music versus diversity of musical traditions
Learning from other tourism destinations \& from intellectual elites, debates about the nature of tourism, culture and minority languages

\section{Institutionalization} (informal and formal rules)

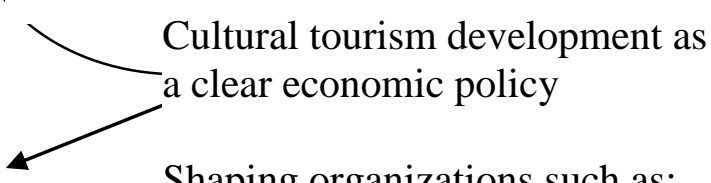

Shaping organizations such as:

Fáilte Ireland Údaras na Gaeltachta Culture Ireland

Arts Council Heritage Council Department of Arts, Sports and Tourism Department of Community, Rural and Gaeltacht Affairs

Figure 4: A model of variables affecting the construction of a new field: cultural tourism. Adapted from Seo and Creed (2002). 
Table 1: Case Study Region

\begin{tabular}{l|l}
\hline Indicators & $\begin{array}{l}\text { Munster } \\
\text { Gaeltacht }\end{array}$ \\
\hline Tourist Revenue (South-West) & $€ 1,028 \mathrm{~m}(2005)$ \\
National Monuments (State- & 37 \\
owned) & 3 \\
Number of Blue Flag Beaches & 3 \\
Institutes of Education & 6 \\
Visitor/Interpretative Centres & 4 \\
Folk Museums & 7 \\
Cultural Tourism (and Language- & \\
Based) Tours & 25 \\
Festivals & 4 \\
Art Centres (County) & 1 \\
International Craft Centres & $€ 2 \mathrm{~m}$ \\
\hline Arts and Crafts Revenue & \\
\hline
\end{tabular}

Data sources: Fáilte Ireland 2005; Domestic Tourism Facts; Kennelly and Dwyer (2000); Kerry County Development Board (2004), Dingle Peninsula Tourism Website. 
Table 2: List of Respondents

\begin{tabular}{l|l}
\hline Organisation & Position \\
\hline Department of Sports, Tourism and & Minister for Sports, Tourism and the Arts \\
the Arts & (Former) \\
Fáilte Ireland & Festivals and Events Officer \\
Fáilte Ireland & Product Management Officer \\
Arts Consultancy & Consultant and advisor to Fáilte Ireland \\
Fáilte Ireland & Manager, Education Policy \\
Fáilte Ireland & Manager, Fellowship Scheme \\
Kerry County Council & Arts Officer \\
Kerry County Council & Heritage Officer \\
An Diseart & Administrator \\
Gaelige Beo & Founder \\
Millstreet & Chief Executive and Financial Controller (2) \\
Championships & \\
Cahirciveen Celtic Music Festival & Committee (5). \\
Feile na Greine & Manager \\
Feile na Bealtaine & Assistant Director (Marketing) \\
Kerry Geo Park & Director \\
Skellig Experience & Manager \\
An Ionad, Blasket Island Centre & Manager \\
Gleninchaquin Park & Founder \\
Puck Fair & PR spokesperson. \\
Sculpture in Stone and Wood & Artist \\
Textiles Art Studio & Craftsperson/founder \\
Cill Rialaig Artists' Retreat & Founder \\
Siopa Cill Rialaig & Manager \\
South Kerry Development Partnership & Manager \\
Residency at Cill Rialaig & Visual Artists (2) \\
Willie Clancy Summer School & Founder \\
Údarás na Gaeltachta & Traditional Arts Officer for Munster \\
Údarás na Gaeltachta & Regional Manager - South \\
Udarás na Gaeltachta & Manager of Policy and Planning (Cultural \\
& Tourism) West \\
Arts Council & Traditional Arts Specialist \\
Total & 36 \\
\hline
\end{tabular}


Table 3 Summary of steps in the case study analysis

\begin{tabular}{|c|c|c|}
\hline Eisenhardt's (1989) steps & & The present study \\
\hline \multirow[t]{2}{*}{ Getting started } & Define research question & $\begin{array}{l}\text { To explore the impact of } \\
\text { social entrepreneurs on the } \\
\text { cultural tourism field and } \\
\text { change in institutional } \\
\text { arrangements }\end{array}$ \\
\hline & $\begin{array}{l}\text { Identify useful a priori } \\
\text { constructs }\end{array}$ & $\begin{array}{l}\text { Institutionalism, social } \\
\text { entrepreneurship, cultural } \\
\text { tourism, socio-economic } \\
\text { development, Gaelic } \\
\text { language and culture }\end{array}$ \\
\hline \multirow[t]{2}{*}{ Selecting cases } & Specify population & $\begin{array}{l}\text { Practitioners and policy } \\
\text { makers in the cultural } \\
\text { tourism sector. }\end{array}$ \\
\hline & Theoretical sampling & $\begin{array}{l}\text { Select respondents, } \\
\text { seeking variety in terms of } \\
\text { type of cultural tourism: } \\
\text { the arts, festival, music } \\
\text { and language tourism. }\end{array}$ \\
\hline \multirow[t]{2}{*}{ Crafting protocols } & $\begin{array}{l}\text { Multiple data collection } \\
\text { methods }\end{array}$ & $\begin{array}{l}\text { Key informant interviews } \\
\text { Group interview, analysis } \\
\text { of websites, tourism }\end{array}$ \\
\hline & $\begin{array}{l}\text { Combine qualitative and } \\
\text { quantitative methods }\end{array}$ & $\begin{array}{l}\text { brochures, policy } \\
\text { documents, survey data. }\end{array}$ \\
\hline \multirow[t]{2}{*}{ Analysing data } & Within case analysis & $\begin{array}{l}\text { Content analysis was used } \\
\text { to identify key themes }\end{array}$ \\
\hline & $\begin{array}{l}\text { Cross case patterns } \\
\text { identified }\end{array}$ & \\
\hline Shaping hypotheses & $\begin{array}{l}\text { Iterative tabulation of } \\
\text { evidence for each concept } \\
\text { across the cases }\end{array}$ & $\begin{array}{l}\text { As themes emerge they are } \\
\text { used to develop a } \\
\text { preliminary conceptual } \\
\text { scheme }\end{array}$ \\
\hline Enfolding literature & $\begin{array}{l}\text { Comparison of findings } \\
\text { with similar and/or } \\
\text { existing literature }\end{array}$ & $\begin{array}{l}\text { Themes from the cases are } \\
\text { used to compare with } \\
\text { findings in the literature }\end{array}$ \\
\hline
\end{tabular}




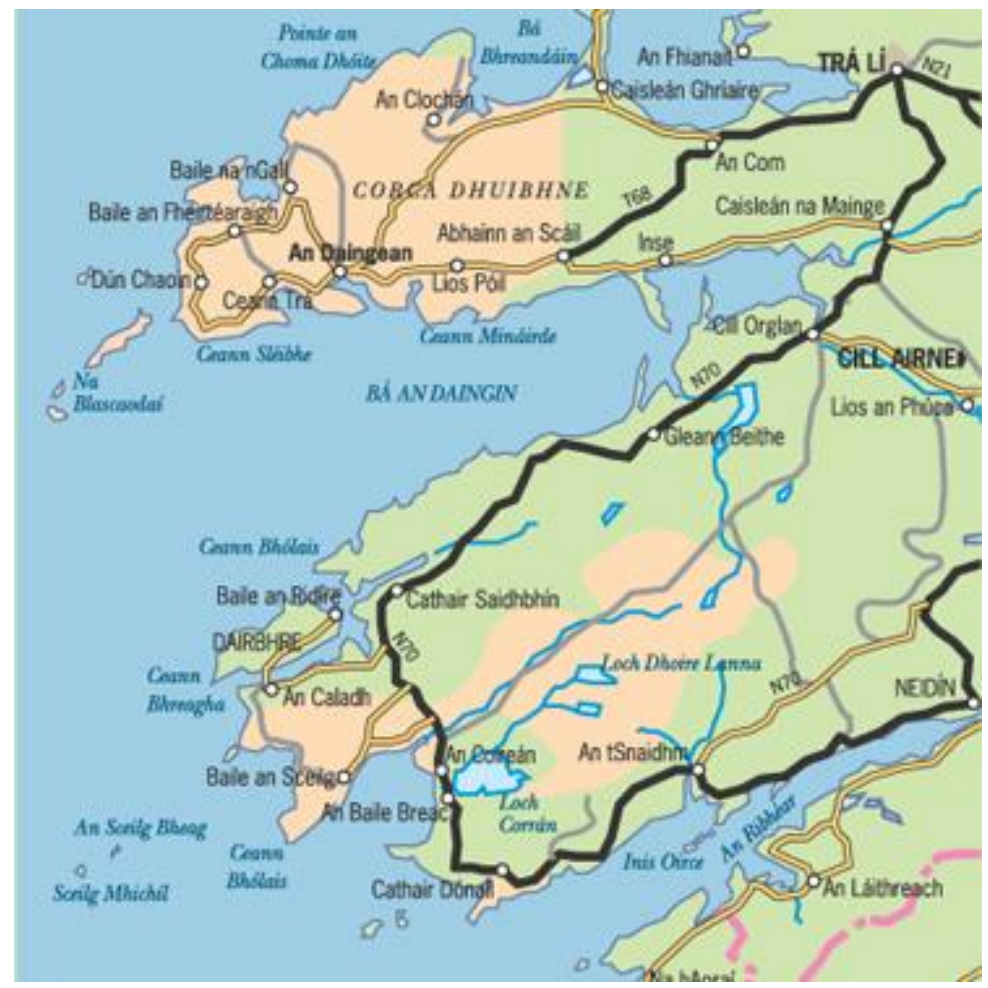

Figure 2: Map of Case Study Region. Source: Údarás na Gaeltachta, available at www.Udaras.ie.

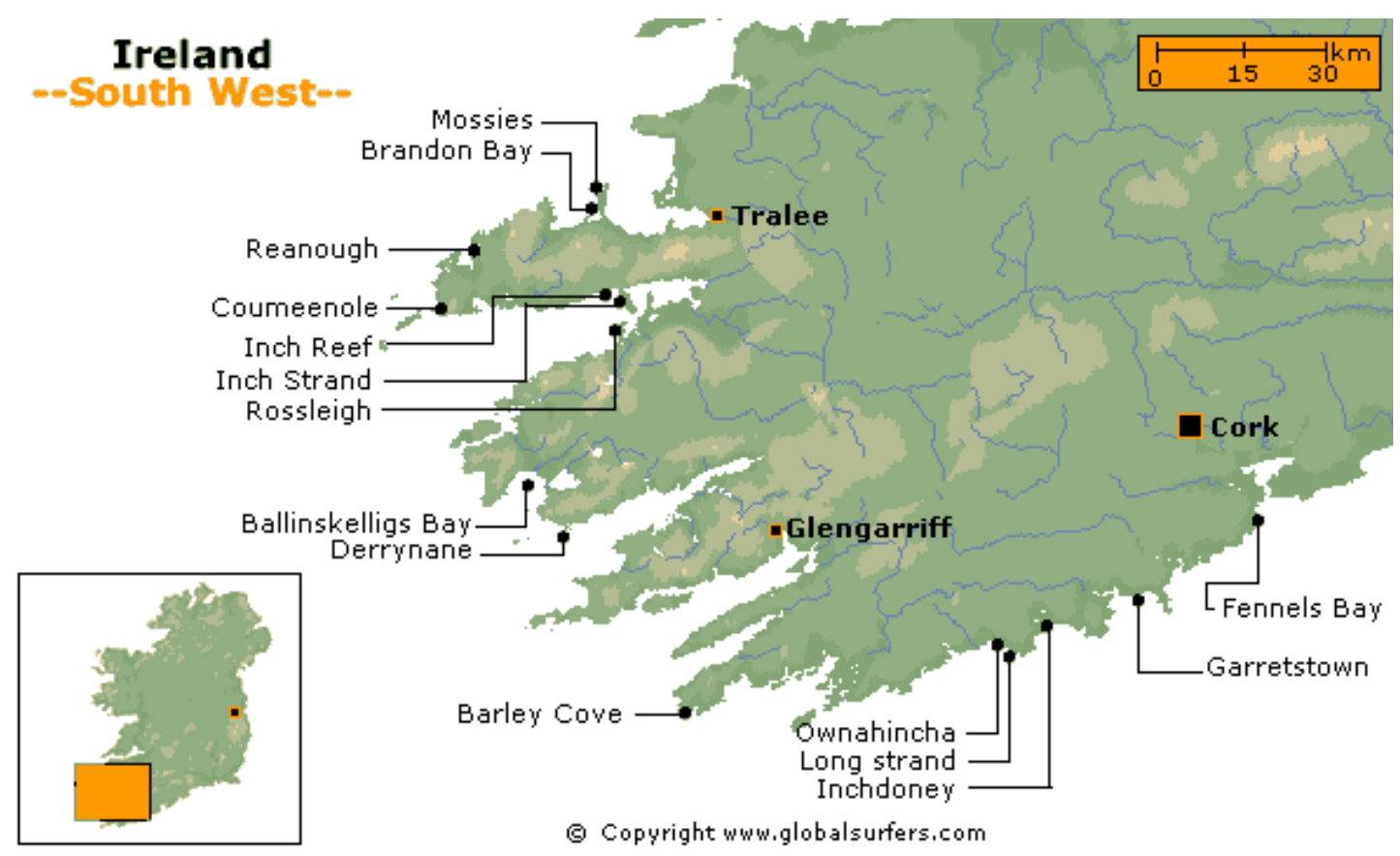

Figure 3: Map of the South West of Ireland. Source: Google Images. 
1 Monetary incentives are targeted at residents in Gaeltacht areas to encourage usage of the language. The Irish government requires a degree of proficiency in Irish for those wishing to teach in primary schools. Irish is a compulsory subject at Leaving Cert level and the state relies on primary and secondary school education to promote the language amongst the non-Irish-speaking community. Irish was recognised as an official EU language in 2005 and is given recognition by the Constitution of Ireland as the national and first official language of Ireland. After the signing of the Good Friday Agreement in 1998, a cross-border body known as Foras na Gaeilge was established to promote the language in both Northern Ireland and the Republic of Ireland.

2 The history of the Dingle name campaign is available on the website http://www.dinglename.com/dingle.htm.

3 Riverdance, which epitomized the revival of Irish culture, was developed from a 5-minute dance routine commissioned for the interval of the Eurovision Song Contest in 1994, which proved to be the highlight of the contest. The show traced the story of Ireland and its people in music, dance and song, traditional and modernized, and incorporated Russian, Spanish, and African American culture where these were encountered by Irish emigrants (Prentice and Anderson, 2000).

$4 \quad$ Bean an Tí refers to a landlady who takes in students who wish to learn Irish in a family setting and she provides lodging, meals as well as education. As well as having a major economic impact in the Gaeltacht, the Bean an Tí is seen as a protector of the Irish language and culture. 